\title{
Railway Natural Industrial Complexes and their Impact on Waterbodies
}

\author{
Strelkov A.K., Teplykh S.Yu., Bukhman N.S. \\ Samara State Technical University, Institute of Architecture and Civil Engineering \\ Address: Molodogvardeyskaya St., 194, Samara, 443001, Russia
}

\begin{abstract}
The paper aims to investigate objects located in railway natural industrial complexes, e.g. the Kuybyshevskaya Railway within the boundaries of Samara region. The authors analyse its following characteristic properties: geometric (proximity to water bodies); intercepted (crossings with bridges or waterbodies); watercut (proximity to subsurface water outlets and high groundwater); hilly-mountainous terrain (washouts and washaways); violation of surface (water drainage from the walls, washaways of flood-prone slopes). The researchers studied a schematic map of the Kuybyshevskaya Railway and came to the conclusion that there is a considerable number of railways crossings with water objects in Samara region, Ulyanovsk region and the Republic of Tatarstan. Some of these railways crossings are located in close proximity to waterbodies. The average value of the crossings is $0.549 \mathrm{~km}$ for every $1 \mathrm{~km}$, i.e. approximately every $500 \mathrm{~m}$ railway tracks cross at least one water object. It means that there is a surface run-off coming from railroad tracks and near-by territories into a waterbody every $500 \mathrm{~m}$. Systematic monitoring of water pollution is performed by a considerable number (up to 20) of gauging stations located within all railroad tracks in Samara region.
\end{abstract}

Keywords: contamination, railway lines, surface runoff, water bodies crossing, spillways, bridges and river crossings.

\section{INTRODUCTION}

Human evolution and creation of industrial methods of economy management have led to the formation of the global technosphere, on of its elements is railway transportation. Natural environment when the elements of the technosphere are operating is the source of raw and energy resources and also space for infrastructure allocation [5]. Successful operation and development of the railway transportation depend on the condition of natural complexes, resource endowment, infrastructure development of induced environment and socio-economic environment. Joint study of the rail transport facilities and natural complexes can be defined as railway natural-technogenic complex (RNTC) followed by formation and impact on the environment [2,21,22].

Whereas, environmental conditions when dealing with RNTC objects depend on infrastructure of railways construction, production, repair and exploitation of railway equipment, manufacturing facilities, penetration level of railway equipment and other object on the railways, penetration of scholarly results in the enterprises and branch objects. Suffice to say that in the Russian Federation railway transportation use up to $7 \%$ of fossil fuels, $6 \%$ of electricity and $4,5 \%$ of timber $[2,5,11]$.

That is why RNTS effect level on the environment is sufficiently large. The nature of impact of transport on the nature is defined by formulation of technical factors, intensity of their impact, ecological weightage of these impacts on the environment elements $[3,19,20]$. Railway pollution is imposed on pollution from agro-industrial activity of enterprises and public utilities. But because of the fact that normally discharge of agro-industrial wastes is occasional and it is forbidden without purification by the Water Code of the Russian Federation and all enterprises are obliged to create and get approval for projects on the Permissible Discharge Standards into Water Bodies. Therefore, it is conceivable that impact from agro-industrial wastewaters discharge on water courses takes place, but insignificant. The calculations are usually performed according to the fishery claims taking into account water down or without it.

In this respect, technogenic impact on the environment can be local (singular factor) or complex (group of various factors) in nature. It is important to make a point of RNTC infrastructural facilities, that have constant, long-lasting-omnipresent effect on water course of the water bodies through surface plate. These effects generally characterized by different ecological hazard coefficients according to type of impact, its character and target exposure $[7,9,12,18]$.

\section{MAIN BODY. THEORY}

As the major object of RNTC research the part of the Kuibyshev railway that is located in the Samara Region is considered. These parameters are shown according to specification: geometrics (proximity to water bodies); river crossings, bridges (water bodies crossing), water-flooded (proximity to subsurface 
water outlet and high subsurface water); hillyhighland country (ablations, erosions); surface drainage violation from the walls, ablations of flooded slopes.

By analyzing schematic map of the Kuibyshev railway it may be concluded that, there is a great number of railway line and water body crossings and also a close proximity of them to the water bodies in the Samara and Ulyanovsk Regions and in the Republic of Tatarstan.

For studying the fluid circuit pollution form close to the railway lines in the Samara region (figure 1) the following five directions (table 1) and groups of railway lines were selected.

According to the proposed directions consider the following parameters of these directions [10,13]: direction length across the Samara Region, number of railway line and water body crossings (including: crossing, bridges, proximity to water body, water cut, hills, slopes, highland country). (Table 2); the watercourse length along the railway lines, $\mathrm{km}$; Catchment area, km2; Universal Combinatorial Impurity Index of the River (UCIIR). The parameters of given directions, taking into account the impact of the railway lines on water bodies, were developed according to the main points of the roadway and railway lines maintenance instruction [10], where maintenance conditions of subgrade, river outlets, strengthening and protective structures are characterized. Protective structures include surface waters retractors (flumes, gutterways, earth trenches); structures for subsoil water capturing and disposing (catchment, earth trenches, captures); strengthening structures (embankment walls, sea walls, wave absorbers and so on); protective structures (mudflow protection structures, landslide protection works, avalanche baffle works and so on).

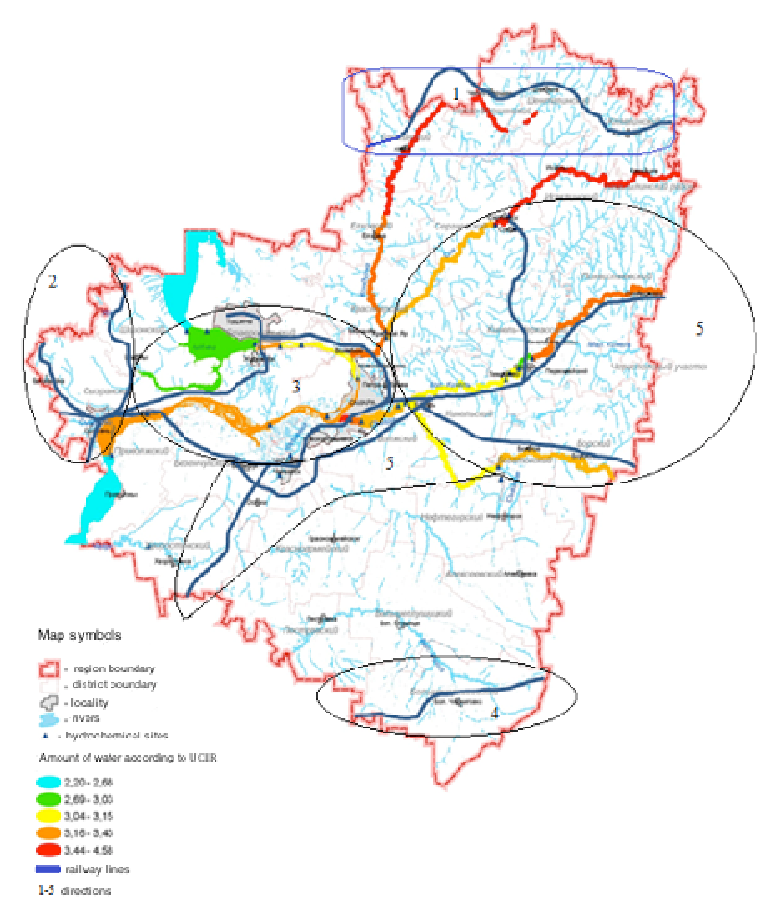

Figure 1. Railway lines direction along the Samara region and their proximity to water bodies.

Table I

Railway lines abd groups alond the samara region

\begin{tabular}{|l|l|l|}
\hline № Line & The nearest branch OAO «Russian Railway» & Group of branch railway lines \\
\hline 1 line & Gorkovskaya railway - branch OAO «Russian Railway» & Koshki-Klyavlino \\
\hline 2 line & Moscovskaya railway - branch OAO «Russian Railway» & Penza-Syzran \\
\hline & Moscovskaya railway - branch OAO «Russian Railway» & Inza-Syzran \\
\hline & $\begin{array}{l}\text { Privolzskaya railway - Moscovskaya railway - branch } \\
\text { OAO «Russian Railway» }\end{array}$ & Saratov-Syzran \\
\hline 3 line & Gorkovskaya railway - branch OAO «Russian Railway» & Ulyanovsk-Syzran \\
\hline & $\begin{array}{l}\text { Kuybischevskayarailway - Gorkovskaya railway - branch } \\
\text { OAO } \text { Russian Railway» }\end{array}$ & Syzran-Zigulesvkoye more \\
\hline & \multicolumn{2}{|l}{ Bezenchuk-Kinel } \\
\hline 4 line & $\begin{array}{l}\text { Privolzskaya railway - Moscovskaya railway - branch } \\
\text { OAO «Russian Railway» }\end{array}$ & Syzran-Samara \\
\hline 5 line & $\begin{array}{l}\text { Privolzskaya railway - Moscovskaya railway - branch } \\
\text { OAO «Russian Railway» }\end{array}$ & Timashevo-Surgut \\
\hline & $\begin{array}{l}\text { Uzno-Uralskaya railway - branch OAO «Russian } \\
\text { Railway» }\end{array}$ & Zvezda - Ishkovo \\
\hline & & Samara-Pohvistnevo \\
\hline
\end{tabular}




\section{EXPERIMENTAL METHOD}

Considered structures protect the roadbed of railways mainly focused on the influence of surface water masses, especially those located in the hilly and mountainous terrain.

It is necessary to talk about the impact of geographic location (hilly and mountainous terrain) railways choice of protective structures, which cause the interception, detention and / or redirection of surface wastewater.

Each form adjacent to or crossing the water body from the railroad tracks, and the transfer takes place flush contaminants located thereon, as well as with the right of way in the surface water body $[6,8,14,15]$.

Table II

Parameters of railway lines in Samara region

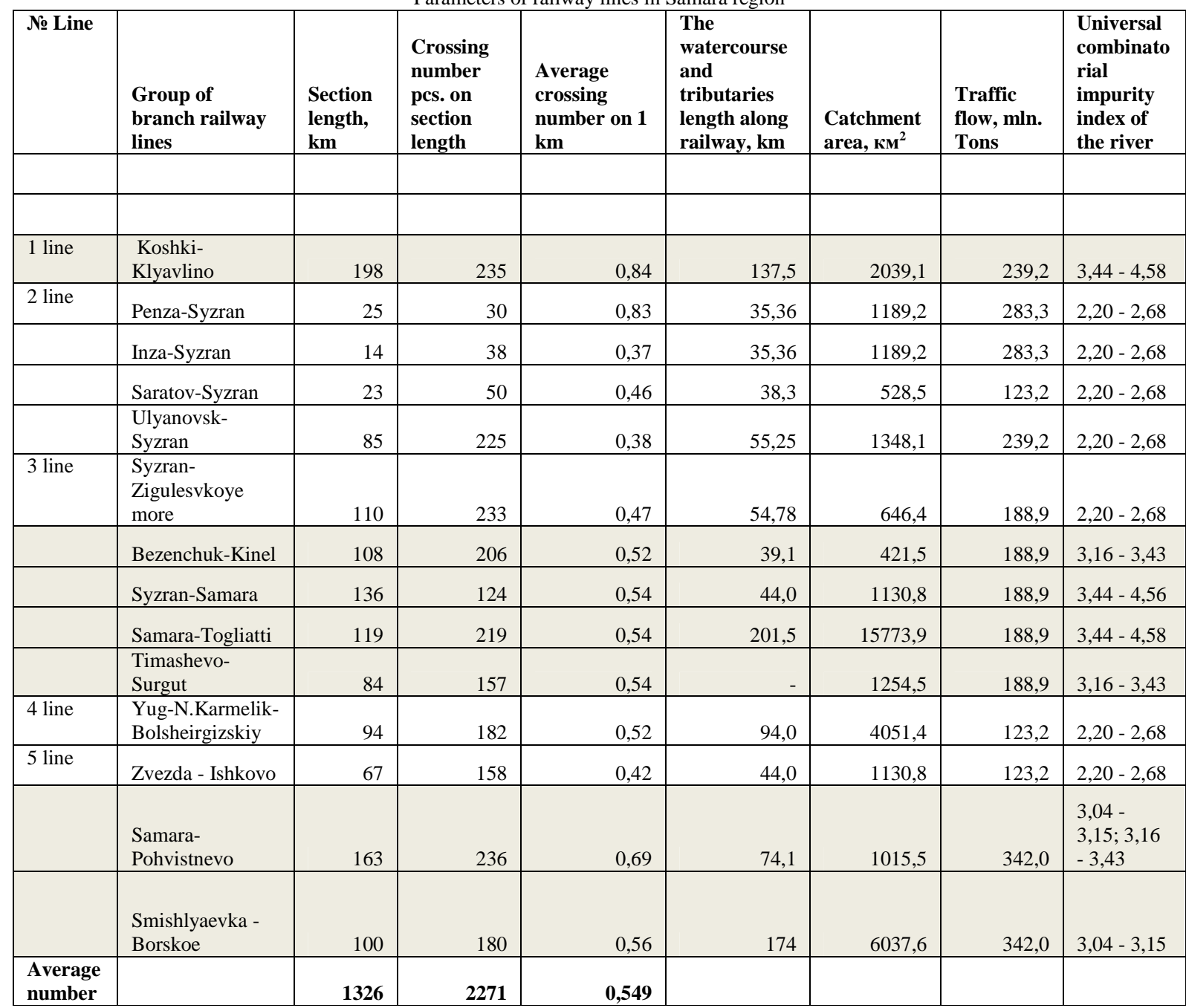

The average crossing number for $1 \mathrm{~km}$ is 0.549 $\mathrm{km}$, so, for every $500 \mathrm{~m}$ accounted for about one crossing railroad lines with a water body. Accordingly, runoff receives each $500 \mathrm{~m}$ in a water body with four sides, washing away polluted, which are on line and the adjacent territory, and they are transported into the reservoir and affect the quality of water composition indicators for water bodies [8.16, 17].

According to the presented table, for each selected direction was determined din of the storm-water drain and tributaries, which are designated catchment area for a single line. Selected areas can be divided into two main groups:
Within each of these groups the lines of the Samara region has a large number of (up to 20) gauging stations [1] conducting systematic monitoring of water pollution, are within each of these group lines in Samara region. For further analysis, we used the following parameters characterizing the water pollution: the concentration of suspended solids mg / 1; oxidation, mg / 1; sulphate concentration mg / 1 ; copper concentration mg / 1; manganese concentration $\mathrm{mg} / 1$.

It should be noted that the level and nature of pollution varies considerably from one to another gauging station within each of these five group lines. Therefore, the empirical mean number (characterizing 
the average level of the relevant residues) and the empirical standard deviations (corresponding parameter characterizing variation within a given group of lines) were found for each of the contaminants in each of the lines the groups listed above.

The results are shown in Table 3. The average number of the corresponding parameter for the respective paths and the group and (after the sign \pm ) its standard deviation from the mean are given in each cell of this table.

The maximum allowable concentration is given in the last row of the table (MAC) of the respective pollution [5].

Table III

The pollutant groups and lines concentration

\begin{tabular}{|l|l|l|l|l|l|}
\hline Group line number & $\begin{array}{l}\text { Suspended } \\
\text { material } \\
\text { concentration } \\
\mathbf{m g} / \mathbf{l}\end{array}$ & $\begin{array}{l}\text { Oxidation } \\
\mathbf{m g} / \mathbf{l}\end{array}$ & $\begin{array}{l}\text { Sulphate } \\
\text { concentration } \\
\mathbf{m g} /\end{array}$ & $\begin{array}{l}\text { Copper concentration } \\
\mathbf{m g} / \mathbf{l}\end{array}$ & $\begin{array}{l}\text { Manganese } \\
\text { concentration } \mathbf{m g} / \\
\mathbf{l}\end{array}$ \\
\hline 1 & $29 \pm 9$ & $6,5 \pm 0,6$ & $450 \pm 150$ & $0,0040 \pm 0,0005$ & $0,95 \pm 0,15$ \\
\hline 2 & $6 \pm 5$ & $7,6 \pm 1,3$ & $100 \pm 18$ & $0,0027 \pm 0,0010$ & $0,28 \pm 0,38$ \\
\hline 3 & $50 \pm 23$ & $5,7 \pm 1,3$ & $321 \pm 132$ & $0,0126 \pm 0,0158$ & $0,132 \pm 0,224$ \\
\hline 4 & $20 \pm 1$ & $6,0 \pm 1,0$ & $72 \pm 14$ & $0,0025 \pm 0,0005$ & $0,020 \pm 0,005$ \\
\hline 5 & $53 \pm 24$ & $5,0 \pm 1,0$ & $254 \pm 59$ & $0,0094 \pm 0,0118$ & $0,041 \pm 0,037$ \\
\hline MAC solicitation & $<7,25$ & $5 \ldots 10$ & $<100$ & $<0,0010$ & $<0,010$ \\
\hline
\end{tabular}

Qualitative pollution level analysis corresponding to the standards for wastewater discharges into water bodies fisheries, is shown in Table 4 .

In this table, sign "+" shows the cell, where pollution is mainly below the norm ( the bulk of the sample corresponds to the standards), the sign "-" shows a cell in which the regulations repeatedly exceeded (that is, the bulk of the sample does not meet the standards) and sign «t» shows the cell in which the average pollution index number differs less from the than the standard deviation (obviously, in this case, an important part of the sample corresponds to the standards, and considerable - does not correspond).

Table IV

Qualitative pollution analysis

\begin{tabular}{|l|c|c|c|c|c|}
\hline $\begin{array}{l}\text { Group line } \\
\text { number }\end{array}$ & $\begin{array}{l}\text { Suspended } \\
\text { material } \\
\text { concentration mg/l }\end{array}$ & Oxidation mg/l & $\begin{array}{l}\text { Sulphate } \\
\text { concentration mg / }\end{array}$ & $\begin{array}{l}\text { Copper } \\
\text { concentration mg / } \\
\text { l }\end{array}$ & $\begin{array}{l}\text { Manganese } \\
\text { concentration mg / } \\
\text { l }\end{array}$ \\
\hline 1 & - & + & - & - & - \\
\hline 2 & \pm & + & \pm & - & - \\
\hline 3 & - & \pm & - & \pm & - \\
\hline 4 & - & \pm & + & - & - \\
\hline 5 & - & \pm & - & - & \pm \\
\hline
\end{tabular}

Table 4 shows that the norm, unfortunately, is an important excess of maximum allowance pollutant concentration.

It should be noted that the level of the maximum allowance concentration in the range of different groups for various types of lines essentially impurities (sometimes many times) differ. Therefore, it is of interest groups the ranging group lines is interesting according to the degree of MAC, so asking the question of what kind of a railway groups are the most or least free from one or another type of pollution. The solution of this problem allows to find out:

- which exactly Kuibyshev Railway lines are firstly needed the environmental measures.

\section{RESULTS AND DISCUSSINGS}

The results of these calculations (made under the assumption of corresponding distribution normality) are shown in Fig. 2 (a-d). In these figures, we can be seen the group railways are numbered in circles and arrows was a statistically important excess of the line pollution level one group over another (the arrow pointing from the group with a lower number of the parameter to a group with a large number of the parameter). Calculations were performed for the two levels of confidence - 68\% (dotted arrows) and 95\% (solid arrows). The necessity of using a relatively low confidence level of $68 \%$ is associated with a fairly high level of pollution parameters desperation within group railways. Thus, conclusions about the larger or lesser oxidation of water within different groups of 
lines generally can be done only in this confidence level (assuming the correct conclusion on average two out of three). The conclusions reached at the confidence level of $95 \%$ (the correct conclusion in 19 cases out of 20), obviously, much more reliable. If the two groups of lines are not connected neither solid nor even the dotted line, it means that a statistically important difference between the groups for this type of pollution lines and almost no difference between the average accidental contamination.

The ranking group on the pollution line level is given in Table 5. In the column of the table groups of roads built by the level of contamination, from the top down, that is the most "polluted" the lines are in the upper row, and the most "pure" - at the bottom. In all cases, except the oxidation, the corresponding parameter number decreases from top to bottom. The presence (or absence) of the dividing line between the numbers of line groups implies the existence (or absence) of a statistically important (at least for a confidence level of $68 \%$ ) the difference between the two. However it should be noted that the presence of groups in various lines one table cell 5 does not mean complete their identity and impossibility of their ranking within the cell. For example, between 3 and 5 groups of oxidation (second column of Table 5), indeed, there is no statistically important difference, as well as between groups 3 and 4; however, this difference is between 3 and 5 groups

This allows us to understand the ranking of tracks on the designated contamination, which allows to make more clearly conclusion about the most polluted railway line groups.

Table V

Ranking of line group on the pollution level

\begin{tabular}{|c|c|c|c|c|}
\hline \multicolumn{5}{|c|}{ Ranking of line group on the pollution level } \\
\hline $\begin{array}{l}\text { Suspended material } \\
\text { concentration } \mathrm{mg} / \mathrm{l}\end{array}$ & Oxidation $\mathrm{mg} / \mathrm{l}$ & $\begin{array}{l}\text { Sulphate } \\
\text { concentration mg / }\end{array}$ & $\begin{array}{l}\text { Copper concentration } \\
\mathrm{mg} / \mathrm{l}\end{array}$ & $\begin{array}{l}\text { Manganese } \\
\text { concentration mg / I }\end{array}$ \\
\hline 5 & \multirow{4}{*}{$\begin{array}{l}5 \\
3 \\
4 \\
1\end{array}$} & 1 & \multirow{3}{*}{$\begin{array}{l}3 \\
5 \\
1\end{array}$} & 1 \\
\hline 3 & & 3 & & \multirow{3}{*}{$\begin{array}{l}2 \\
3 \\
5\end{array}$} \\
\hline 1 & & 5 & & \\
\hline 4 & & 2 & \multirow{2}{*}{$\begin{array}{l}2 \\
4\end{array}$} & \\
\hline 2 & 2 & 4 & & 4 \\
\hline
\end{tabular}

According to the ranking given in Table 5 that the concentration suspended solids and oxidation ranging practically the same. We can understand that the second group of line, it ends in the line to Syzran; it does not make any important pollution in water bodies. A fifth and third are the most introduced by contamination to the make our environment more polluted. The most prosperous on the sulfates, copper and manganese concentration is fourth group of roads, the least happy is the first one. And the first line, located in the North, through which passes cargo tonnage mainly from the Urals and the Ural metallurgical company, importantly contaminated with metal salts.

The exposure level analysis of the transported cargo tonnage in five areas of several railways OAO "Russian Railways" and its comparison with the quality of water for at the universal combinatorial impurity index transit mass transfer of pollutants on water areas in Samara region.

Found communication, in consequence, the found similar things will allow to predict the maximum contamination of watercourse pollution from lines, with a choice of potentially dangerous line for the pollutants, for immediate repair or reconstruction of the protective drainage facilities.

\section{V.CONCLUSION}

It is necessary for the Kuibyshev railway (the branch of OAO Russian Railway (RR) in the Samara
Region) to pay attention to the repair and reconstruction of RNTC principal objects: along spillways, small bridges and bridge crossing by railway line and water body crossings and give attention to the following (the "dirtiest" - ref. table 5) directions: the first, third, fifth, where a great number of crossings per one kilometre were identified and proved by UCIIR index.

It is advisable for the Kuibyshev railway (the branch of OAO Russian Railway (RR) in the Samara Region) to do urgent environmental action in order to prevent pollution from RNTC objects in water bodies i.e. to allocate petit combine purification plants (filter cartridges) for the surface runoff coming from the territory of railway bridges, bridge crossing, river outlets, strengthening and protective structures.

\section{REFERENCES}

[1] http://www.pogoda-sv.ru/nets/ [elektronny resurs Gidrometeorologicheskie stantsii i posty - Samarskaya oblast] [electronic resource - Hydrometeorological stations and posts of the Samara Region].

[2] Teplykh S.Yu., Strelkov A.K. Characteristics of railroad natural-technogenic complexes. Procedia Engineering, V. 111, 2015, pp. 742-747.

[3] Strelkov A.K, Teplykh S.Yu, Bukhman N.S. Liquid filtration properties in gravel foundation of railroad tracks. Journal of Physics: Conference Series, 738(1), 2016, 012124.

[4] Bogomolov O.A. Ekonomika i ekologiya zheleznodorozhnogo transporta $v$ sovremennyh REALIYAH [Economics and ecology of the raileay transportation in the modern world]. Internet-zhurnal Naukovedenie [Online magazine Science Studies], 1(6), 2011, pp.12-28. 
[5] Gosudarstvenny doklad o sostoyanii okruzhayushchey sredy i prirodnyh resursov Samarskoy oblasti [State report on the state of the environment and natural resources of the Samara region], 2014, pp. 298.

[6] Strelkov A.K., Teplykh S.Yu., Gorshkalev P.A., Korenkova S.F., Sargsyan A.M. Opredelenie kontsentratsiy zagryazneniy $\mathrm{v}$ poverhnostnom stoke $\mathrm{s}$ zheleznodorozhnyh putey kosvennym metodom [Evaluation of pollutional load in the surface runoff coming from the railway lines using indirect method]. Vodosnabzhenie i sanitarnaya tekhnika [Water supply and sanitary engineering], 8, 2013, pp. 67-70

[7] Strelkov A.K., Teplykh S.Yu., Gorshkalev P.A., Sargsyan A.M. Otsenka ekologicheskogo sostoyaniya tekhnicheskoy polosy otvoda [Assessment of ecological condition of strip of branch of railway tracks]. Put i putevoe hozyaystvo [Road and Track facilities], 3, 2014, pp. 31-34.

[8] Teplykh S.Yu., Sargsyan A.M. Vliyanie poverhnostnogo stoka s putey na vodnye obekty [The impact of surface runoff coming from railway lines on water bodies]. Put i putevoe hozyaystvo [Road and Track facilities], 5, 2012, pp. 27-29.

[9] Teplykh S.Yu., Sargsyan A.M. Zagryaznenie vodnyh obektov poverhnostnymi stokami $\mathrm{s}$ prilegayushchih putey zheleznodorozhnyh stantsiy [Pollution of the water bodies by the surface runoffs coming from the railway lines]. Vodoochistka [water cleaning], 2, 2012, pp. 31-32.

[10] TSP-544 Instruktsiya po soderzhaniyu zemlyanogo polotna zheleznodorozhnogo puti [Instruction on railway line roadway maintenance], M.,Transport, 2000, 100 p.

[11] Strelkov A.K, Teplykh S. Yu., Stepanov S.V., Sargsyan A.M. Monitoring pollution level in railroad right-of-way. Procedia Environmental Sciences, 32, 2016, pp. 147-154.

[12] Teplykh S.Yu., Sargsyan A.M. Evaluation and Prediction of Water Pollution by Surface Runoffs from Adjacent Ways of Railway Stations. IWA Regional Conference on Wastewater Purification and Reuse. 28th, 29th, And 30th of March, Heraklion, Crete, Greece, 2012, 67 p.

[13] Gorshkalev P.A., Teplykh S.Yu., Stok s zheleznodorozhnyh putey. Kompleksnaya sistema opredeleniya kachestvennyh i kolichestvennyh pokazateley (monografiya) [Surface runoff coming from the railway lines. The complex system of qualitative and quantitative indexes definition], LAP LAMBERT Academic Publishing GmbH \& Co. KG, 2011, $148 \mathrm{p}$.

[14] Teplykh S.Yu., Sargsyan A.M. Rassmotrenie i prognoz zagryazneniy vodnyh obektov poverhnostnymi stokami s prilegayushchih putey zheleznodorozhnyh stantsiy [Pollution of the water bodies by the surface runoff coming from the railway lines]. IX Mezhdunarodnyy vodnyy forum. Mezhdunarodnaya nauchno-prakticheskaya konferentsiya «Voda I Dovkillya» Kiev [IX International Water Forum. International research-to-practice conference "Aqua Ukraine" Kiev], 2011, pp. 140-141.

[15] Strelkov A.K., Teplykh S.Yu., Gorshkalev P.A.. Izuchenie kachestvennyh harakteristik poverhnostnogo stoka $\mathrm{s}$ zheleznodorozhnyh putey [Studing quality characteristics of surface runoff coming from railways]. Urban construction and architecture, 1(9), 2013, pp.61-68.

[16] Strelkov A.K., Teplykh S.Yu., Gorshkalev P.A., Sargsyan A.M. Ekologicheskie aspekty vozdeystviya poverhnostnyh stochnyh vod s zheleznodorozhnyh stantsiy [Nature of oil pollutions oil from railways]. Urban construction and architecture, 4(13), 2013, pp.83-88.

[17] Strelkov A.K., Teplykh S.Yu., Gorshkalev P.A., Sargsyan A.M. Sovremennoe sostoyanie voprosa sbora i ochistki poverhnostnogo stoka s zheleznoy dorogi [Modern condition of the problem of collecting and purifying rail way surface drainage]. Science review, 4, 2014, pp. 123-129.

[18] Strelkov A.K., Teplykh S.Yu., Sargsyan A.M. Vliyanie obektov zheleznodorozhnogo transporta na gidrosferu [The impact of railway transportation objects on hydrosphere]. Geoekologiya zhilogo doma. geodinamicheski aktivnye razlomy $\mathrm{i}$ ih vozdeystvie na zdorove i zhiznedeyatelnost cheloveka. I Nauchno-prakticheskaya konferentsiya s mezhdunarodnym uchastiem [Geoecology of the living house. Geodynamic active faults and their impact on health and human activity. Research-to-practice conference with international participation], 2014, pp. 88-91.

[19] Strelkov A.K., Teplykh S.Yu., Gorshkalev P.A., Sargsyan A.M. Vzaimodeystvie obektov zheleznodorozhnogo transporta i ekosistemy [Interection between railway transportation and ecosystem]. Tekhnologii ochistki vody «TEKHNOVOD-2014»: materialy VIII Mezhdunarodnoy nauchno-prakticheskoy konferentsii; Krasnaya Polyana, g. Sochi [Water purification technologies "TEKHNOVOD2014" Materials of VIII International research-to-practice conference; Krasnaya Polyana, city of Sochi] / YuzhnoRossiyskiy gosudarstvennyy politekhnicheskiy universitet (NPI) [South-Russian State Technical University (NPI)], 2014, pp.181-184.

[20] Teplykh S.Yu., Buhman N.S., Sargsyan A.M. Issledovanie polosy otvoda zheleznodorozhnyh putey na nalichie zagryazneniy [Study into the presence of pollution in the right-of-way railway zone]. Science review, 9, 2014, pp. 802808 .

[21] Strelkov A.K., Teplykh S.Yu.,.Buhman N.S., Sargsyan A.M. Analiz i harakteristika filtratsii poverhnostnogo stoka $\mathrm{V}$ ballastnoy prizme zheleznodorozhnogo puti [Analysis and specifications of filtration of surface runoff from railway track ballast section]. Vodosnabzhenie i sanitarnaya tekhnika: ezhemesyachnyy nauchno-tekhnicheskiy i proizvodstvennyy zhurnal [Water supply and sanitary engineering: scientifictechnical monthly journal], 12, 2015, pp. 63-72.

[22] Strelkov A.K., Teplykh S.Yu. Metodologiya i metody otsenki zheleznodorozhnyh prirodno-tekhnogennyh kompleksov i struktur [Evaluation methodology and methods of railway natural-technogenic complexes and structures]. Mezhdunarodnyy vodny forum EKVATEK-2016. Konferentsiya «Sovershenstvovanie sistem vodopolzovaniya promyshlennyh predpriyatiy» [International water forum EKVATEK-2016. Conference entitled Water management Improvement at Industrial enterprises], 2016. 